\title{
Sonegação de Impostos, Deficit Orçamentário e Inflação
}

U

M dos mais graves problemas que afligem hoje a vida brasileira é, sem dúvida, a inflação. O ritmo a que alcançou nos últimos anos é de tal maneira acelerado que se o Govêrno não tomar medidas imediatas capazes de controlá-la, estarão sèriamente ameaçadas as instituições politicas e a paz social.

As tensões alimentadas pelo processo inflacionátio agravam-se dia a dia. O constante e desordenado aumento do custo-de-vida reduz o poder de compra das classes pobres, exigindo, em conseqüência, a elevação dos niveis salariais que, por sua vez, vêm influir no agravamento do processo, gerando-se, assim, verdadeiro circulo vicioso.

As revisões de salário mínimo que antes se faziam em periodos prolongados, passaram a ser feitas anualmente e tendem a tornar-se cada vez mais freqüentes, sem contudo tesolver-se o problema, pois, logo decretado o nôvo salário, os preços sobem vertiginosamente e os trabalhadores continuam na situação antetior, isto é, sem poder de compra.

Tem-se reconhecido, no Brasil, que a principal causa dessa inflação galopante são as vultosas emissões de papel-moeda realizadas pelo Govêrno Federal para financiar os deficits de caixa do Tesouro. Êsses deficits - cobertos quase que integralmente com emissões - já se elevam a mais de $25 \%$ da receita, convindo assinalar que no exercicio corrente essa percentagem ultrapassará a cifra dos $50 \%$.

O aumento dos meios de pagamento suscitado por essas emissões sem guardar nenhuma consonância com o crescimento teal da produção, é fator decisivo no ativamento da pressão inflacionária. De fato, enquanto no periodo de 1955 a 1960, os indices do produto real (produto interno bruto) subiram de 100,0 para 132,6 , os meios de pagamento elevaram-se de $177.923 \mathrm{mi}$ lhôes de cruzeitos para 693.032 milhões de cruzeiros, acompa- 
nhando o ritmo de aumento do meio circulante que ascendeu de 69.340 milhões de cruzeiros para 206.140 milhões de cruzeiros, actisando o deflator implicito, no periodo, uma elevação de 100,0 para 261,7 .

Conseguido que seja o equilibrio orçamentário, embora não se tenha chegado ao exterminio completo da inflação, pois não é a sua única causa, ter-se-á reduzido de muito o seu ritmo de crescimento, completando se a operação, pela adoção de outras medidas econômico-financeiras. É, por conseguinte, o desequilibrio orçamentário um dos mais importantes fatôres para o aceleramento do processo inflacionário, entre nós.

Para obter-se o equilibrio de um orçamento deficitário, deve-se ou reduzir as despesas ou aumentar a receita. A primeira hipótese, no caso brasileiro, não é aconselhável, pois somos um pais em franco desenvolvimento e a paralisação das obras nos setores prioritários da infra-estrutura teria implicações as mais funestas, tanto do ponto-de vista econômico como do social, neste, pela imensa massa de desemprêgo que ocasionaria. Impõe-se, portanto, a segunda solução.

Nos Estados modernos, pelo menos no mundo não socialista, a fonte principal de receita é a arrecadação de impostos, constitutindo, no Brasil, a renda tributária, $90 \%$ da receita orçamentária. 0 equilibrio do orçamento nacional deve ser atingido, de tôda evidência, através de um aumento na arrecadação dos tributos, consistente não sòmente na elevação das taxas de incidência, mas, sobretudo, num combate sistemático às fraudes fiscais que parecem ocorrer em escala ostensivamente larga. Quem examina as estatisticas pertinentes à matéria, chega a conclusões estarrecedoras, mormente no que toca ao impôsto de renda.

Segundo o Anuário Estatístico do Brasil (1961), públicado pelo Conselho Nacional de Estatistica, dos 70.799.352 habitantes existentes em 1960 apenas 358.242 pagaram impôsto de renda, naquele exercício, escapando à tributação 70.441 .110 pessoas, ou seja, 99,5\% da população. Ao tempo, eram considerados, por lei, contribuintes do impôsto de renda tôdas as pessoas fisicas domiciliadas ou residentes no Brasil, que tivessem renda liquida anual superior a Cr\$90.000,00 (noventa mil cruzeiros). Esses números, não obstante a baixa renda per capita do brasileiro (Cr $\$ 20.920,00$. 
no ano base de 1959) são altamente expressivos da ocortência de enorme sonegação no pagamento do impôsto.

Há, porém, aspectos mais graves e chocantes, segundo a mesma fonte, e que evidenciam uma escandalosa fraude à legislação do impôsto de renda. No ano em referência (1960), apenas 251 pessoas, em todo o pais, declararam renda liquida superior a $\mathrm{Cr} \$ 4.500 .000,00$ (quatro milhóes e quinhentos mil cruzeitos) e em oito Estados da Federação nenhuma pessoa atingiu essa tenda, sendo que no Ceará e no Rio Grande do Norte ninguém teve renda sequer superior a Cr\$ 3.000.000,00 (três milhões de crlizeiros).

Em Minas Gerais, Estado sabidamente de sólidas fortunas, sòmente seis pessoas ultrapassaram aquêle limite de Cr $\$ 4.500 .000,00$. enquanto que em São Paulo, surpreendentemente, o número de contribuintes que excederam êsse montante foi inferior ao do Estado da Guanabara: 89 contra 104. As pessoas com tenda superior a $C r \$ 3.000 .000,00$ (770, ao todo no pais) pagaram menos de um bilhão e meio de cruzeitos de impôsto (impôsto sôbre pessoas fisicas), para uma arrecadação superior a onze bilhões e meio, o que comprova serem, os componentes da classe média, os grandes contribuintes do impôsto de renda no Brasil.

Os dados expostos, como ficou dito, denunciam a existência de substancial evasão na arrecadação do impôsto de renda e explicam sua baixa rentabilidade e sua colocação em segundo plano no nosso sistema tributário. As conseqüências dai decorrentes são de suma importância, afetando profundamente as finanças do pais.

Em primeiro lugar, essa evasão produz o desequilibrio orçamentário, forçando o Govêrno a financiar o deficit de caixa por meios inflacionários, como a emissão de papel-moeda, com a conseqüente agravação de problema do custo-de-vida. Dá ênfase aos impostos indiretos, particularmente ao impôsto de consumo, que se apresentam de maior produtividade, estimulando os dirigentes a procurar nêles os recursos de que necessitam para equilibtar os orçamentos estatais. Tal procedimento conduz a uma inevitável repercussão nos preços das mercadorias e a uma flagrante injustiça social inerente a essa espécie de tributos que incidem, indistintamente, sôbre as pessoas, sem qualquer consideração à sua capacidade contributiva. Finalmente, deixa-se de realizar a verdadeira justiça fiscal, que consiste em retirar -se dos 
que têm muito, para aplicar em obras püblicas, de interêsse coletivo, beneficiando-se, assim, os menos favorecidos.

Urge, portanto, combater com rigor essas fraudes, e, para fazêlo, indispensável se torna melhorat o aparelho fiscalizador, com uma reforma total do Ministétio da Fazenda, em bases racionais, dotando-se os setus quadros, sobretudo os de fiscalização, de maior número de funcionátios selecionados em concurso público; criando-se cadastros perfeitos dos contribuintes; reaparelhando-se, com o material necessário, as diversas repartiçóes: estabelecendo-se um sistema eficiente e rápido de intercomunicações cntre os vários órgãos espalhados por todo o pais; e instituindo-se uma policia fiscal para as investigações e sindicâncias destinadas a evitar a sonegação tributátia e possibilitar a punição criminal dos fraudadores.

Sem a adoção dessas medidas nenhuma reforma tributária dará os resultados desejados porque a sonegação continuará cada vez maior. As providências tendentes a implantá-las iá foram. no entanto, tomadas pelo Conselho de Ministros, através de vários projetos de lei que encaminhou, em matço do ano em curso, ao Congresso Nacional, os quais consubstanciam a chamada "Reforma Geral do Ministério da Fazenda". Surge, assim, uma esperança de solução do problema. 